\title{
A.G. van Aarde en historiese Jesus-navorsing
}

\begin{tabular}{|c|c|}
\hline \multicolumn{2}{|c|}{$\begin{array}{l}\text { Author: } \\
\text { Gerrit-Daan van der Merwe }{ }^{1}\end{array}$} \\
\hline \multicolumn{2}{|c|}{$\begin{array}{l}\text { Affiliation: } \\
{ }^{1} \text { Department of New } \\
\text { Testament Studies, Faculty } \\
\text { of Theology, University of } \\
\text { Pretoria, South Africa }\end{array}$} \\
\hline \multicolumn{2}{|c|}{$\begin{array}{l}\text { Note: } \\
\text { This article is an adaptation } \\
\text { of parts of a MDiv } \\
\text { dissertation, completed } \\
\text { under Prof. Ernest van Eck } \\
\text { in the Department of New } \\
\text { Testament Studies of the } \\
\text { Faculty of Theology at the } \\
\text { University of Pretoria in } \\
2013 \text {. The article is meant } \\
\text { as a tribute to the } 15 \text { year } \\
\text { anniversary of the existence } \\
\text { of the Reformed Theological } \\
\text { College at the Faculty of } \\
\text { Theology of the University of } \\
\text { Pretoria. }\end{array}$} \\
\hline \multicolumn{2}{|c|}{$\begin{array}{l}\text { Correspondence to: } \\
\text { Gerrit-Daan van der Merwe }\end{array}$} \\
\hline \multicolumn{2}{|c|}{$\begin{array}{l}\text { Email: } \\
\text { gerritdaan@gmail.com }\end{array}$} \\
\hline \multicolumn{2}{|c|}{$\begin{array}{l}\text { Postal address: } \\
\text { PO Box 12372, Hatfield 0028, } \\
\text { South Africa }\end{array}$} \\
\hline \multicolumn{2}{|c|}{$\begin{array}{l}\text { Dates: } \\
\text { Received: } 09 \text { May } 2015 \\
\text { Accepted: } 18 \text { July } 2015 \\
\text { Published: } 30 \text { Sept. } 2015\end{array}$} \\
\hline \multicolumn{2}{|c|}{$\begin{array}{l}\text { How to cite this article: } \\
\text { Van der Merwe, G-D., } \\
\text { 2015, 'A.G. van Aarde en } \\
\text { historiese Jesus-navorsing', } \\
\text { HTS Teologiese Studies/ } \\
\text { Theological Studies 71(3), } \\
\text { Art. \#3056, } 7 \text { pages. http:// } \\
\text { dx.doi.org/10.4102/hts. } \\
\text { v71i3.3056 }\end{array}$} \\
\hline \multicolumn{2}{|c|}{$\begin{array}{l}\text { Copyright: } \\
\text { (C) 2015. The Authors. } \\
\text { Licensee: AOSIS } \\
\text { OpenJournals. This work is } \\
\text { licensed under the Creative } \\
\text { Commons Attribution } \\
\text { License. }\end{array}$} \\
\hline \multirow[b]{2}{*}{ 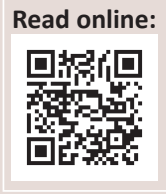 } & \\
\hline & $\begin{array}{l}\text { Scan this QR } \\
\text { code with your } \\
\text { smart phone or } \\
\text { mobile device } \\
\text { to read online. }\end{array}$ \\
\hline
\end{tabular}

A.G. van Aarde and historical Jesus research. A.G. van Aarde's contribution to historical Jesus research is mainly expressed in his book Fatherless in Galilee: Jesus as Child of God. The book was the result of five years of Jesus research. Van Aarde is an ordained minister of the Netherdutch Reformed Church of Africa (NRCA). Since the book's publication in 2001, the NRCA has experienced an immense dispute regarding the book in particular but also regarding the subject of historical Jesus research in general. This dispute has publicly escalated since 2010. It has often centred on Van Aarde's notion of Jesus' fatherlessness. This article will focus on said book in order to ascertain what is meant by the concept the fatherless Jesus'. This is done to illustrate that Van Aarde's research, as it converges in the scrutinised publication, remains of relevance to the NRCA.

\section{Fatherless in Galilee: Jesus as child of God}

Tydens 'n openbare lesing wat op 31 Oktober 2012 deur die Hervormde Teologiese Kollege (HTK) aan die Universiteit van Pretoria aangebied is, ${ }^{1}$ dui A.G. van Aarde (2013a) sy motivering om die boek Fatherless in Galilee: Jesus as child of God te skryf soos volg aan:

Die doel van die boek is om in voortdurend veranderende tyd die gesig van God in Jesus te herken en te erken. Anders gesê, dit gaan oor God se openbaring in en deur Jesus wat ons bely as Christus, Here en God. (bl. 2 van 8)

Volgens Van Aarde is die boek 'n poging om hierdie geloofsbelydenis in die lig van wetenskaplike kennis teen die agtergrond van die sosio-ekologiese, politieke en ekonomiese toestand van die een en twintigste eeuse wêreld te verantwoord. Hy toon aan dat navorsing oor die historiese Jesus begin wanneer 'n mens 'n massa antieke tekste kronologies orden (Van Aarde 2013a:2 van 8).

\section{Uitdagings in die navorsing}

Van Aarde (2013a:4 van 8) dui aan dat navorsing oor die historiese Jesus problematies is aangesien beskikbare inligting skaars is. Die oudste kanoniese geskrifte, die briewe van Paulus, bevat minimale verwysings na Jesus se aardse lewe en verwys glad nie na sy gelykenisse of wonderwerke nie (Van Aarde 2013a:4 van 8). In navorsing oor die historiese Jesus is hierdie afwesigheid van verwysings na Jesus se lewe voor sy kruisiging in die Pauliniese literatuur problematies aangesien die Christelike literatuur wat die naaste stratum van Jesus-tradisies verteenwoordig nie na die historiese Jesus se lewe verwys nie. Die noodwendige gevolg is dat die vroegste Christelike literatuur nie Jesus se eie verkondiging voortsit nie. Met ander woorde, 'n gesaghebbende deel van vroeg-Christelike literatuur lewer geen perspektief op die historiese Jesus of op sy verkondiging nie. Navorsers moet hulleself noodgedwonge na latere skriftelike tradisies en ekstra-kanoniese geskrifte wend.

Van Aarde (2013a:3-4 van 8) wys daarop dat Rudolf Bultmann ([1933] 1969:223-235) reeds in 1933 aangetoon het dat daar 'n onderskeid, maar nie noodwendig 'n diskontinuïteit nie, tussen die leringe van (die historiese) Jesus en die verkondiging aan en van die vroeë kerk getref behoort te word. Die oorspronklike leringe van Jesus asook die kerklike verkondiging vind volgens Bultmann ([1933] 1969:223-235) uitdrukking in die verkondiging oor die koninkryk van God. Van Aarde (2001:20) stem saam met Bultmann ([1933] 1969:223-235) dat Paulus dit nie nodig geag het om sy verkondiging in 'Jesus die Jood' te grond nie aangesien dit dan noodwendig verkondiging sou wees wat op 'n bepaalde kulturele konteks gebaseer is en nie op die geloofslewe binne die ruimte van diegene wat deel van die koninkryk van God geword het nie.

Van Aarde (2001:20-21) is dit ook eens met Osborn (1990:221) dat dit nie akkuraat sou wees om te sê dat Paulus vir Jesus slegs as 'vleeslik', dit wil sê as 'n Jood, beskou het en nie ook- 
veral nie - as die opgestane Christus nie. Paulus het die voor- en na-Pase Jesus as ' $n$ Jood beskou, maar hy het nie sy Messiasskap tot 'n bloot etniese aangeleentheid gereken nie. Met ander woorde, Paulus ontken nie Jesus se kulturele agtergrond nie, maar besef dat Jesus se kulturaliteit nie die fokus van Jesus se lewe en verkondiging is nie. Daar is beslis 'n saaklike kontinuiteit tussen die Jesus van Nasaret en die Jesus wat deur Paulus as Christus en Here verkondig word. Paulus vind dit nie nodig om Jesus se lewe of wonderwerke oor te vertel nie, want dit is vir hom nie funksioneel nie. Regverdiging deur geloof alléén, en die implikasies vir die lewe wat híerdie geloof inhou, is vir Paulus van belang. Die 'wat' van Jesus se lewe word nie deur Paulus ontken nie, maar ook nie beklemtoon nie. Die 'hoe' (etiek) van die gelowige se lewe is vir Paulus belangrik. Hierdie etiek is gebaseer op die etiek van Jesus wat tegelyk 'vleeslik' 'n Israeliet is en 'geestelik' die Christus, die Here, die Kind (Seun) van God is. Paulus is oortuig dat menslike onderskeidings nie vir Jesus belangrik was nie. Van Aarde (2001:21) wys daarop dat Paulus alleen hierdie 'lewe in Christus' begrond omdat hy reeds kennis van die bestaande Jesus-tradisies gehad het. Die Jesus van die geskiedenis is daarom relevant, nie net vir die verstaan van Paulus se verkondiging nie, maar wel ook om daarteen te waak dat Paulus se verkondiging nie Jesus se boodskap vervang nie (Van Aarde 2001:21; vgl. Käsemann 1969:23-65).

Alhoewel Paulus baie min oor die historiese Jesus sê, vind Van Aarde (2013a:4 van 8) sy uitgangspunt juis in Paulus se werk. Ten einde Jesus 'histories' te benader, wend Van Aarde (2001:51-52) 2 Korintiërs 5:21 as sleutelteks aan. Hy (Van Aarde 2001:51-52; 2013a:4 van 8) toon aan dat Paulus se uitdrukking 'tot sonde gemaak' 'n idiomatiese uitdrukking is wat daarna verwys dat kinders in 'n bose wêreld gebore word. In sy kommentaar op die Tweede Korintiërbrief bevestig Bultmann ([1940-1950] [1976] 1985:164-160) ook hierdie gedagtegang en voer aan dat soortgelyke uitsprake in kontemporêre literatuur sê dat 'onskuldige babas' en 'kinders nie weet wat die kwaad is nie' (Bultmann ([1940-1950] [1976] 1985:165). Vir Paulus kan Jesus vergelyk word met sulke onskuldige kinders wat in die boosheid van die wêreld verstrengel geraak het. Nietemin het Jesus in sy onskuld soos 'n misdadiger gesterf (Van Aarde 2001:53). Die geloofslewe van Christus-volgelinge as herskape mense veronderstel deelname aan die lewe van hierdie 'onskuldige Jesus'. Van Aarde se bogenoemde bespreking van Paulus se interpretasie van die Jesus-tradisie demonstreer hoe ingewikkeld dit is om deur middel van die vroegste kanonieke tekste by die vroegste stratum van die Jesus-tradisies oor die historiese Jesus uit te kom.

Van Aarde (2012) wys op 'n tweede uitdaging wat hy in sy Jesus-navorsing moes hanteer het. Dit is die wyse waarop die oudste evangelie, dié van Markus (Van Aarde 2013a:4 van 8), geïnterpreteer word. In die Markusevangelie word Jesus slegs as volwassene aangetref. As 'n mens die insigte van geesteswetenskappe soos die psigologie in ag neem, moet aanvaar word dat die kinderjare ' $n$ deurslaggewende rol in die identiteitsvorming en optrede van 'n volwassene speel. ${ }^{2}$ Vanuit hierdie perspektief beskou, is dit dus problematies dat die oudste aanvaarde weergawe van die lewe van Jesus geen verwysing na sy kindwees bevat nie. Nog meer so as ons die sterk invloed van die familiale verbintenisse in die eerste-eeuse Mediterreense wêreld in ag neem (Van Aarde 2001:74-75, 119-134).

'n Verdere probleem in historiese ondersoeke oor die algemeen en navorsing oor die historiese Jesus in die besonder is dat sommige gebeurtenisse hulleself nie tot die veld van historiese wetenskaplike studie leen nie. Die gebeure tussen God en mens is volgens Van Aarde (2013a:4 van 8) so 'n aangeleentheid. Hy dui aan dat die tegniese term 'mite' in die godsdienswetenskap ingespan word om na tekste te verwys wat oor die interaksie tussen God en mens handel. Mites is volgens Van Aarde (2001:48-49) in die pre-wetenskaplike era gebruik om die interaksie tussen die natuurlike en bo-natuurlike wêrelde uit te druk (vgl. Van Aarde 1999:441-444). Van Aarde verduidelik die konsep 'mite' verder deur aan te sluit by Barthes (1957:142-243) wat die funksie van mites beskryf as die 'leegmaak van realiteit' en 'n poging om die 'leë geskiedenis' met 'natuur' vol te maak. Mitologie is aan die hand van hierdie beskrywing die projeksie van realiteit op 'n denkbeeldige wêreld (die leegmaak van realiteit). Die denkbeeldige wêreld bestaan uit beelde wat met alledaagse gebeurtenisse ooreenstem (die leë geskiedenis wat met natuur gevul word). Terwyl sommige mites waarskynlik fantasie is, kan ander as die projeksie van 'ware' verhale beskou word. Hoe dit ook al sy, die term 'mite' verwys na nie-empiriese ervaring. Van Aarde span die term op historiese wyse in, dit wil sê, wanneer Van Aarde van die mites in Bybelse tekste praat, verwys hy na die ware verhale wat nie volgens wetenskaplike kriteria histories ondersoek kan word nie (God-mens; bonatuurlike-natuurlike interaksie). Anders gestel, mites is vir Van Aarde simboliese taal wat na legitieme ervaring van nie-geobjektiveerde gebeurtenisse verwys. Volgens Van Aarde (2013a:4 van 8) is die verhale oor die paradys, die hiernamaals, God se verwekking van Jesus, God se opwekking van Jesus uit die dood, Jesus se hemelvaart en Jesus se wederkoms sulke tekste wat nie histories-krities ondersoek kan word nie. Jesus se doop is volgens Van Aarde (1999:438) die 'hoofgebeurtenis' waarin ons met Jesus as 'Seun van God' kennis maak. Die geboorteverhale oor Jesus kommunikeer as mitiese tekste volgens Van Aarde 'n soortgelyke boodskap as dié oor die doop van Jesus.

\section{Van Aarde se historiese navorsing oor Jesus Jesus se doop}

Andersasmiteskan Jesus selewe welkrities ophistoriografiese wyse ondersoek word. Hierdie aanname voorveronderstel dat die verhaal oor Jesus wel na die lewe van 'n spesifieke historiese figuur verwys. Van Aarde (2013a:4 van 8) erken die beperkings waaraan 'n historiese ondersoek na Jesus 2.Kyk na Dorn et al. (2006:30-56) en Levpušček (2006:238-264). 
van Nasaret onderwerp is, spesifiek wat Jesus se kinderjare betref. Die enigste beskikbare bronne is die tekste wat as mitiese tekste beskryf word (Van Aarde 2013a:4 van 8). Die metodologiese benadering wat Van Aarde (2001:46) gebruik, is 'sosiaal-wetenskaplik-krities' van aard (kyk na Van Aarde \& Joubert 2009:419-456). Dit behels onder andere 'n 'kruiskulturele antropologie en sosiale psigologie' (vgl. Van Eck 2012:55). Ten opsigte van navorsing oor die historiese Jesus word die metode aangewend om die idee van 'n 'vaderlose Jesus' vanuit die perspektief van 'n 'ideaal-tipe' van Max Weber se sosiologiese benadering te ondersoek.

In ondersoeke na die historiese Jesus neem sowel die New Quest ${ }^{3}$ as die Renewed New Quest ${ }^{4}$ hulle vertrekpunt in die doop van Jesus toe Hy reeds 30 jaar oud was. Van Aarde (2001:53) is van mening dat ' $\mathrm{n}$ 'historiese' ondersoek na Jesus verder teruggevoer behoort te word en wel tot by die geboortetradisies. Daar is reeds vroeër na die probleem verwys wat die oudste evangelie, te wete Markus, in hierdie verband lewer. Markus begin sy vertelling met Jesus as volwassene. Die Evangelies van Matteus en Lukas bevat geboorteverhale, maar werp nie veel lig op Jesus se kinderjare nie. Van Aarde (2001:53) dui twee moontlike redes aan waarom daar nie ander verwysings na Jesus se kinderjare is nie, afgesien van die apologeties-konfessionele en legendariese 'kindheidsmateriaal' in die Nuwe Testament (vgl. Luk 2:41-52). Eerstens is dit moontlik dat die inligting bloot nie onder die vroeë Christene bekend was nie. Tweedens is dit moontlik dat die eerste-eeuse Mediterreense mense alleen outoriteit aan mans koppel wat reeds een of ander religieuse inisiasierite ondergaan het wat die oorgang van kind na volwassene simboliseer. Die realiteit is dat Jesus wel voor sy doop 'n geskiedenis moes gehad het aangesien geen historiese figuur as 'n dertigjarige volwassene gebore word nie.

Die vraag in enige historiese ondersoek na Jesus sou dan wees wat die relevante gebeure of omstandighede is wat Jesus se doop voorafgegaan het. Bultmann ([1926] 1988:13, [1960] 1965:11, n. 17) sowel as Jeremias (1971:42) beskou volgens Van Aarde (2001:54) Jesus se verhouding met Johannes die Doper as die deurslaggewende 'wat' wat Jesus se doop voorafgegaan het. Bultmann ([1921]1967:263) voer aan dat die historisiteit van Jesus se doop nieteenstaande die vertellings wat ons daarvan het, 'n 'legende' is. Hy erken dus die hoogs waarskynlike historisiteit van die gebeure, maar beskou die weergawes (Matt 3:13-17; Mark 1:9-11; Luk 3:21-22) as geredigeer om sekere apologetiese doeleindes te bereik. Dit het te make met die eerste-eeuse verstaan van die doop, te wete, die reiniging van sonde. Vir die vroeë Christene was dit moontlik 'n verleentheid om Jesus se doop te verduidelik

3.Die New Quest was'n akademiese beweging wat in verband met historiese Jesusnavorsing die standpunt gehandhaaf het dat die evangelies na ' $n$ historiese persoon (Jesus van Nasaret) verwys alhoewel 'n biografie van daardie persoon nie uit die evangelies saamgestel kan word nie. Daar word gevra na die kontinuïteit tussen die voor- en na-Pase Jesus.

4.Die Renewed New Quest is die beweging wat historiese Jesus-navorsing onderneem, onder andere die werk van die Jesus Seminar. Hierdie beweging beskou gebeure wat waarskynlik 'histories' was as van groter belang as die Christologiese of belydenismatige interpretasie van die gebeure. Van Aarde, hoewel lid van die Jesus Seminar, deel nie hierdie opinie nie en oordeel dat die relevansie van historiese Seminar, deel nie hierdie opinie nie en oordeel dat die relevansie van
Jesus-navorsing verskeie fasette het (kyk na Van Aarde 2001:195-204). aangesien dit impliseer dat Hy van sonde gereinig moes word. Die historiese gebeure van sy doop was wel van belang anders kon dit uit die evangelies weggelaat geword het om die verleentheid te vermy. Die verhaal is daarom geredigeer (vgl. Matt 3:14) $)^{5}$ om die doop van 'n sondelose man te regverdig (vgl. Bultmann [1921] 1967:253). Van Aarde (2001:57) toon aan dat Bultmann (1952:34) nie probeer het om die gebeure wat die doop voorafgegaan het, te identifiseer of te tipeer nie, maar nogtans erken het dat daar wel voorafgebeure moes gewees het, dit wil sê daar moes 'n rede vir Jesus se doop wees. Johannes die Doper se optrede was gemik op die reiniging van sonde deur die doop. Bultmann (1952:34) meen dat Jesus se doop ook hierdie funksie ten doel gehad het. Hy vra egter nie na die aard of agtergrond van Jesus se sogenaamde 'sonde' nie, maar neem op grond van 2 Korintiërs 5:21 (vgl. ook Joh 7:18; 8:46; Heb 4:15; 1 Joh 3:5) aan dat Jesus sy sonde onskuldig gedra het en die doop, net soos die kruisdood, daarvoor moes ervaar (Van Aarde 2001:57). Van Aarde sluit hier by Bultmann aan. Soos hierbo aangetoon, veronderstel Van Aarde ook dat 2 Korintiërs 5:21 aandui dat Jesus, ten spyte van sy onskuld, die doop as reiniging van sonde moes ontvang. Anders as Bultmann, meen Van Aarde egter dat die historisiteit van Jesus se lewe voor sy doop, spesifiek met verwysing na sy geboorteverhaal en kinderjare, sy doop in perspektief stel.

\section{Jesus se identiteit in die milieu van 'n eerste-eeuse Mediterreense, Joodse gemeenskap}

Die afwesigheid van inligting oor Jesus se kinderjare in die kanonieke en intra-kanonieke geskrifte plaas uiteraard 'n beperking op historiese ondersoeke na hierdie onderwerp. Dit is egter moontlik om die kultuur-historiese milieu te rekonstrueer en logiese afleidings as 'hipotese' ${ }^{6}$ aan te bied. Van Aarde (2012) voer aan dat die familie en spesifiek die vader in die antieke kultuur'n sentrale rol gespeel het (vgl. Van Aarde 1994:92-93; Van Eck 2009:468). Die geboortevertellings in die kanonieke evangelies, te wete Matteus en Lukas, kan mitologies beskou word in die sin van God-mens interaksie wat nie deur middel van 'n histories-kritiese ondersoek op 'wetenskaplike' wyse histories geverifieer kan word nie. Selfs al sou ons die geboortevertellings in Matteus en Lukas as 'histories' beskou, laat dit ons steeds met 'n skets van Jesus wat nie 'n biologiese vader gehad het nie - en dit in 'n sosiokulturele milieu waar vaderloosheid verdoemend was. Enige Joodse kind wat nie uit die sosiaal aanvaarbare huwelik tussen 'volbloed' Israeliete gebore is nie, is as buite-egtelik beskou (Van Aarde 2001:73-74, 111).

Van Aarde $(2001: 73-74,111)$ toon aan dat daar gedurende die eerste twee eeue na Jesus se geboorte gerugte versprei is dat

5.Kyk veral na die Evangelie van Nasireërs (in Hiëronimus, Contra Pelagius 3.2) en die Evangelie van die Ebioniete (in Epiphanius, Haereseis 30.13.7-8). Vir hierdie tekste, kyk na Tatum (1994:89-90).

6.Van Aarde (2004:225-226) volg egter nie 'n positiwistiese (deterministiese) deduktiewe benadering nie, maar op ' $n$ postmoderne 'abduktiewe' wyse formuleer deduktiewe benadering nie, maar op ' $n$ postmoderne 'abduktiewe' wyse formuleer
hy ' $n$ 'hipotese' wat op grond van bevindings, voortspruitend uit die ondersoek na die data, gewysig, bevestig of afgewys kan word. 
Jesus óf uit 'n immorele buite-egtelike verhouding óf uit die verkragting van sy moeder gebore is. Hy neem egter duidelik standpunt in dat hierdie gerugte nie historiese gronde het nie en dat dit lasterlike leuens was wat ingespan is om Jesus, Jesus se ma en sy volgelinge te diskrediteer. Gedurende sy openbare lesing in 2012 stel Van Aarde (2013a:4 van 8) dit dan ook eksplisiet dat hierdie soort verdagmaking sowel Jesus as sy moeder se eerbaarheid aangetas het. Nietemin het Jesus se 'ongewone herkoms' dus heel waarskynlik aan Hom die sosiale titel van 'n buite-egtelike kind om die nek gehang. Die term 'buite-egtelik' verwys egter nie uitsluitlik na immorele verhoudings soos wat die moderne mens dit verstaan nie. Van Aarde (2001:73) wys daarop dat swanger vrouens wat deur hulle mans verlaat is, die stigma 'hoer ${ }^{7}$ ontvang het, ten spyte van die feit dat dit die man is wat in so 'n geval immoreel opgetree het. Gevolglik is die kind wat deur so 'n vrou in die wêreld gebring is as die produk van owerspel beskou. Dit is vanselfsprekend dat die tempelideologie kinders wat uit sonde (owerspel) gebore is as onrein (sistemies sondig ${ }^{8}$ ) beskou het. Uit voorbeelde soos hierdie is die patriargale, sosiaal-onbarmhartige strukture waarteen Jesus dit gehad het, baie duidelik.

Van Aarde (2001:74) dui verder aan dat ook kinders wat uit huwelike tussen Jood en nie-Jood gebore is as buite-egtelike kinders beskou is. Die kinders van geskeide vrouens en etnies gemengde huwelike is sosiaal as vaderloos of buiteegtelik beskou en was as sodanig illegitiem. Op grond van Deuteronomium 23:3 (vgl. Van Aarde 2001:74) is sulke 'illegitieme' mans verbied om die tempel in te gaan of selfs om met 'ware Israeliete' (wat nie uit gemengde huwelike gebore is nie) te trou. Ander gevalle waar geboortes as illegitiem beskou is, sluit verwekking deur immoraliteit, verkragting, bloedskande en verleiding in. Sulke kinders wat illegitiem gebore is, is nie gereken onder die 'kinders van Abraham' nie en was dus identiteitloos in die Joodse gemeenskap.

Van Aarde (2001:77) wys daarop dat Christelike bronne tussen 30 en 70 n.C. nie van Josef of enige ander historiese figuur as Jesus se vader melding maak nie. By die latere opskrifstellings van Matteus (ca. 85-95 n.C.) en Lukas (85 n.C.) word in die geboortevertellings (Matt 1:17-25; 2:13-14, 19-23; Luk 1:27; 2:4-5, 16) na Josef as vaderfiguur verwys. Wat Jesus se kinderjare betref, is daar slegs een teks wat na Josef se teenwoordigheid verwys, te wete, Lukas 2:41-51. 'n Sosiokulturele hermeneutiese benadering is volgens Van Aarde (2013a:5 van 8) nodig vir 'n uitleg van hierdie vertelling. Hy voer aan dat kindwees volgens die antieke opvoedkunde vanaf drie-jarige ouderdom tot en met puberteit gestrek het. Teen twaalfjarige ouderdom was die meeste kinders in die Romeinse en Israelse samelewing se formele 'skoolopleiding' verby. In antieke skrywers se werk is dit 'n herhaaldelike tegniek om heldefigure as kinders uit te beeld wat reeds oor die besondere eienskappe beskik waarvoor hulle later

7.Die term 'hoer' is in hierdie geval ' $\mathrm{n}$ neerhalende skelwoord wat gebruik word om vrouens met onaanvaarbare seksuele gebruike te etiketteer.

8.Sistemiese sonde verwys na die etiek van ' $n$ betrokke sisteem wat op so 'n wyse toegepas word dat mense in die sisteem passief skuldig raak aan oortredings (vgl. Borg 2011:80-82) beroemd sou raak. Die normale eienskappe wat gewoonlik met kinders geassosieer word, byvoorbeeld speelsheid, onskuld, impulsiwiteit of ongehoorsaamheid, is nie in sulke tekste teenwoordig nie, maar word vervang met die betrokke kultuur se deugde waarvoor volwasse helde bekend was, byvoorbeeld wysheid en beheerstheid. Hierdie literêre tegniek is ' $n$ algemene verskynsel in die 'kindheidsvertellings van vereerde persone in die Grieks-Romeinse literatuur' (Van Aarde 2013a:5 van 8). Die betrokke passasie (Luk 2:41-51) is deur 'n Griekse geleerde geskryf wat met hierdie gebruik bekend was en hy het dit moontlik ingespan (Van Aarde 2013a:5) om Jesus se vereerde status te beklemtoon deur sy gesag van kleins af aan te dui. Jesus se geleerdheid word volgens Lukas egter nie van sy ouers ontvang nie, maar van God. Lukas span dus hierdie tegniek in teen die agtergrond van sy eie kultuur om aan te toon dat Jesus die Seun van God is. Op grond hiervan sê Van Aarde (2013a):

Josef se teenwoordigheid saam met die twaalfjarige Jesus in die tempel wat die rabbi's God se wysheid leer, behoort myns insiens eerder as 'n literêre motief verstaan te word as dat dit biografiese geskiedskrywing sou wees. (bl. 5 van 8 )

In Hoofstuk 4 van Fatherless in Galilee sit Van Aarde (2001:83-118) die ontwikkeling van die Josef-tradisie uiteen. Hiervolgens word die Ou-Testamentiese karakter Josef gebruik as literêre motief in Joods-Hellenistiese geskrifte wat in dieselfde tyd as Matteus, Lukas en Johannes ontstaan het. Hierdie motief, asook ander gebruike uit die omringende kontekste van die evangelieskrywers, is aanduibaar deur die verskille tussen die kanonieke evangelies aan te toon:

In die Evangelie van Matteus, die Israeliet, kom die verhaal van die maagdelike verwekking voor. Matteus vergelyk Jesus met Moses. Joods-Rabbynse literatuur bevat tradisies wat hulle oorsprong in Matteus se tyd het. Hierdie tradisies berig dat Moses ook uit 'n maagd gebore is, hoewel die Ou Testament niks daarvan sê nie. Josef vervul in Matteus die hoofrol. God verskyn in 'n droom aan Josef. In Lukas speel Maria die hoofrol en die engel kommunikeer met haar en nie met Josef nie. In die evangelie van Lukas, die Griek, is Griekse invloede sigbaar. Jesus se geboorte uit die Heilige Gees kan vergelyk word met die wonderbaarlike geboortes van Grieks-Romeinse figure, soos dié van Julius Caesar en Caesar se aangenome seun Augustus, die eerste Romeinse keiser in wie se regeertyd Jesus gebore is. ' $n$ Baie bekende verhaal oor 'n maagdelike verwekking in Lukas se tyd is dié van die skrywer Ovidius wat berig oor die wonderkind Perseus. (Van Aarde 2013a:5-8; vgl. Van Aarde 2001:162-165)

Selfs indien Josef wel 'n historiese figuur was, weerspreek dit nie die bevinding dat Jesus as 'illegitiem' beskou is nie aangesien die Josef waarna Matteus en Lukas verwys, baie vroeg van die toneel verdwyn (vgl. Van Aarde 2012:5). Of Josef histories bestaan het, is volgens Van Aarde (2013a:5 van 8) 'n bysaak aangesien die getuienis oor Jesus se openbare optrede nooit na sy vader verwys nie. Die kerkvader Epifanius het in die vierde eeu probeer om Josef se afwesigheid te verduidelik deur aan te voer dat hy vroeg in Jesus se lewe gesterf het. Dit is die tradisionele beskouing wat vandag steeds deur sommige Nuwe-Testamentici soos J.P. Meier (1991:317) aanvaar word. Van Aarde (2001:116) kritiseer egter vir Meier aangesien dit na sy mening nie moontlik is 
om patristiese getuienis as histories outentiek te beskou as daardie getuienis nie deur onafhanklike vroeëre getuienis, soos byvoorbeeld die Nuwe Testament, ondersteun word nie. Terwyl Van Aarde (2001:116) dit met Meier eens is dat Josef se vaderskap neutraal tot Jesus se optrede is, verskil hy van Meier wat aanvoer dat hierdie neutraliteit nie vir die evangelieskrywers van belang sou gewees het nie. ' $n$ Manlike figuur sonder 'n vader in die Mediterreense wêreld was 'n man sonder identiteit, en hierdie feit is te verreikend om te ignoreer en as nie-bepalend vir mense in die tyd van Jesus en die skrywers van die Nuwe Testament te beskou.

Van Aarde (2001:74) verwys na verskeie onafhanklike bronne wat aandui dat Jesus se 'buite-egtelikheid' wel ernstig geneem moet word, naamlik die Thomasevangelie, die Markusevangelie en dele van Matteus en Lukas wat nie die Markus-tradisie voortsit nie, asook Johannes. In Markus 6:3 word na Jesus verwys as die 'seun van Maria'. Hierdie verwysing dui aan dat Jesus nie in die Joodse gemeenskap 'n identiteit gehad het nie aangesien na sy moeder verwys word en nie na sy vader soos dit die gebruik was nie. Matteus 27:64 verwys volgens Van Aarde moontlik na 'n lasterveldtog teen Matteus se gemeenskap waarvolgens Matteus se vermelding van die 'eerste bedrog' waarskynlik na die belydenis van Jesus se verwekking deur die Gees en legitimering deur God verwys en die 'laaste bedrog' dan die verkondiging van sy opwekking uit die dood sou wees. In Johannes 19:9 vra Pilatus vir Jesus waar Hy vandaan kom en Jesus swyg. Op grond van Rabbynse literatuur (vgl. Kiddushin 4:2) weet ons dat kinders wat nie geweet het wie hulle ouers is nie, verplig was om te swyg indien so 'n vraag aan hulle gestel word.

Van Aarde (2001) bring hierdie 'buite-egtelikheid' van Jesus in sy Joodse gemeenskap in verband met Jesus se doop. Die gebeure wat sy doop voorafgaan - en noodsaak - is die sosiale paradigma van die tyd. Dit wil sê, Jesus word in sy eie gemeenskap beskou as 'sondaar', nie op grond van immoraliteit of ongehoorsaamheid aan God nie, maar bloot omdat sy moeder ongetroud was met sy verwekking en sy vader afwesig was in sy lewe. Die doop reinig Jesus nie alleen van die sistemiese sonde wat aan Hom toegeken is nie, maar legitimeer Hom ook as persoon deurdat God Jesus as kind erken.

Jesus se vaderloosheid is volgens Van Aarde (2012) bepalend vir sy handelinge gedurende sy openbare optrede. Deur 'n breedvoerige verduideliking van identiteitsvorming in samelewings soos die een waarin Jesus gebore is, dui Van Aarde (2001:119-127) aan dat Jacobs-Malina (1993:48-55) se argumente aangaande Jesus se sosiale rolvervulling korrek is. Volgens Jacobs-Malina vertoon Jesus in sy optrede gedrag wat eerder met vroulike rolle in die eerste-eeuse Mediterreense, patriargale, patrilokale samelewing te identifiseer is as met dié van mans. Hierdie gedrag sluit onder andere in om te dien, vergifnis, sagmoedigheid en medelye en die versorging of genesing van wonde of siekte (Van Aarde 2001:124). Van Aarde (2001:125) verskil egter van Jacobs-Malina wanneer sy aanvoer dat Jesus se lewe 'n metaforiese raamwerk bied waarin Jesus die rol van 'n getroude vrou inneem en oor die huishouding waak terwyl haar man (God) van die huis af weg is. Op grond van die tekstuele gegewens verstaan Van Aarde die metaforiese raamwerk eerder as die vaderseun verhouding. Die afwesigheid van 'n vader in hierdie kultuur laat ' $n$ vakuum van sosiale identifikasie aangesien die seun nie die 'verhardende' manlike ontwikkelingsbaan kan voltooi wat onder die vader se opvoeding sou plaasvind nie. Aangesien Jesus na God as 'sy Vader' verwys, oordeel Van Aarde (2001:134) dat dit wil voorkom of Jesus se volgelinge sy lyding geïnterpreteer het as die optrede van 'n gehoorsame Seun wat Homself aan sy Vader se wil onderwerp. Sy primêre identifikasie wat - soos met alle seuns van dié tyd - deur sy verhouding met 'n moederfiguur gevorm is, het op grond van sy vaderloosheid nooit in die sekondêre identifikasie met 'n manlike figuur oorgeloop nie. Daarom dan dat sy optrede eerder die vroulike kwaliteite van die samelewing weerspieël. Hy tree egter as man in 'n patriargale samelewing op en hierdie deugde wat gewoonlik aan vroulike rolle gekoppel is, spreek dus spontaan en is intensioneel teen patriargale gebruike gerig.

Van Aarde (2001:139-140) toon aan dat kinders en spesifiek babas aan die sosio-kulturele, politieke en religieuse onkunde en bygeloof van antieke samelewings uitgelewer was. Daar was waarskynlik niemand meer weerloos as kinders in samelewings soos dié van Jesus nie. Jesus se eie ervaring van 'illegitimiteit' stel sy besondere bemoeienis met kinders in perspektief. Van Aarde se navorsing dui aan dat daar volgens die sosio-kulturele samestelling van Jesus se tyd niks eerbaars, besonder of selfs gewoon aanvaarbaar in Jesus se lewe voor sy doop was nie. Vanuit die perspektief van die sosiale wêreld waarin Hy grootgeword het, was Hy 'n niemand of 'n nikswerd. Hierdie status was uiteraard vernederend, en deur Jesus as God te erken, word die vernedering ook na God verplaas. Ten spyte van Jesus se identiteitsvorming as Seun van God is sy lewe op vernederende wyse beëindig. Van Aarde (2013a:6 van 8) wys daarop dat Artikels 18 en 19 van die Nederlandse Geloofsbelydenis (1561; vgl. Die diensboek van die NHKA 1987:143-145), sowel as die Heidelbergse Kategismus (1536), Vraag en Antwoord 35 en 36 (vgl. NHKA 1987:177), die God-met-ons belydenis beklemtoon wanneer hierdie belydenisskrifte Jesus se menswording in terme van swakheid, menslikheid en vernedering uitdruk.

\section{Die kerk en belydenisskrifte}

Aangesien Jesus se opstanding uit die dood vir Van Aarde (2013a:4 van 8) onder die mitologiese vertellings van die kanonieke evangelies val, kan hierdie 'gebeure' nie aan 'n histories-wetenskaplike ondersoek onderwerp word nie. Verdere ondersoek moet daarom fokus op die mense en strukture wat Jesus se opstanding verkondig het. Jesus se inklusiewe en anti-hiërargiese verkondiging dui volgens Van Aarde (2001:184) aan dat sy doel nie was om 'n struktuur soos die kerk te vestig nie. Hierin is hy dit eens met Trilling (1978:68). Van Aarde (2001:185) voer aan dat Jesus in die kerklike verkondiging opgestaan het. Dit wil sê Jesus het voortgeleef en leef steeds voort deur die voortdurende en 
opeenvolgende verkondiging van sy saak. ${ }^{9}$ Hierdie proses van oorlewering het aanleiding gegee tot die ontwikkeling van verskeie Jesus-tradisies (vgl. Schille 1994:104; Schillebeeckx 1974:38) wat tot by Jesus se volgelinge, by name Maria Magdalena, Petrus, Jakobus en Paulus, teruggevoer kan word. Sommige vroeë Christene het die verskyning van die opgestane Christus as die 'Seun van die mens' ervaar. Hierdie ervarings kan sosiaal-wetenskaplik met behulp van die konsep 'altererende bewussyn' verduidelik word (vgl. Groenewald \& Van Aarde 2006). Hierdie Seun van die mens sou vir hulle ' $n$ apokaliptiese figuur wees wat aandui dat die begin van die einde vir die swaarkry van hulle tyd aangebreek het. Ander se geloof was gebaseer op die verkondiging van mense soos Paulus wat deur die verheerlikte Christus self gestuur is (Van Aarde 2001:185). Die bewerings dat Maria Magdalena die eerste persoon was wat die opgestane Here gesien het, blyk volgens Van Aarde (2001:185-186) histories outentiek te wees. Uit die bronne wat die verhaal vertel van die vroue wat Jesus na sy opstanding gesien het, is daar slegs een, te wete Epistula Apostolorum, wat Maria Magdalena nie as die eerste van die 'getuies' aandui nie. Die verbasing oor die getuienis van die vroue onder Jesus se dissipels het te make met die sosio-kulturele en sosio-godsdienstige omstandighede van die tyd. Vroue se getuienis is eenvoudig nie as betroubaar geag nie. Jesus verskyn egter ook aan Petrus en die vergadering van al die dissipels (Luk 24:36-49; Joh 20:19-23, 26-29). Hierdie tradisie beklemtoon onder andere die geloof in die herstel van die 'totaliteit van Israel'. 'n Ander tradisie neem as die begin van die verspreiding van die Jesus-saak die gebeure wat in Handelinge 2:1-42 weergegee word. Volgens hierdie tradisie vervang Jesus, die Messias, die tempelkultus en godsdienstige rites oor die vergifnis van sonde. Alle mense uit alle nasies het nou vrye toegang tot God, en die doop in Jesus Christus se Naam is die teken van hulle geestelike vernuwing (Van Aarde 2001:186).

Volgens Van Aarde (2001:189) is die dade en woorde van die historiese Jesus wat verband hou met inklusiwiteit en egalitariteit ook daardie woorde en dade wat uitgedruk is deur die faksie wat as die kerk (ekklēsia) bekend geraak het. Daarom is die vorming van die kerk nie as sodanig 'n diskontinuiteit met Jesus se werk nie.

\section{Bevinding}

Van Eck (2012:64) oordeel dat enige historiese navorsing in die teologie in 'n stadium aan die vraagstuk aangaande die historiese Jesus sal moet aandag skenk. Enige ondersoek na die bronne waarvan die Nuwe-Testamentiese skrywers gebruik gemaak het, sal noodwendig die historiese Jesus as vertrekpunt moet neem (vgl. Van Aarde 2001:203). Dit geld ook vir die ondersoek na die Sitze-im-Leben en die teologiese tendense van Nuwe-Testamentiese geskrifte en hulle bronne. In hierdie opsig is navorsing oor die historiese Jesus van groot belang vir historiese, literêre en teologiese navorsing. Wanneer daar met die genres van die evangelies

9.Vir Van Aarde se verstaan van die vroeë Christene se opstandingsgeloof, kyk na sy (Van Aarde 2013b:31-48) publikasie 'The tomb cult of the early Jesus-followers in Jerusalem' erns gemaak word, tree die verhouding tussen die voor-Pase Jesus en die na-Pase Jesus op die voorgrond. Die literêre samestelling en redaksie van die kanonieke evangelies verweef die voor- en na-Pase Jesus-periodes deur die voorPase Jesus-tradisies op die na-Pase Jesus-gemeenskappe te projekteer. So word die twee historiese wêrelde saam in 'n verhaalvorm opgeneem en oorgelewer. Die wêreld van die na-Pase Jesus-gemeenskap (verkondigde Jesus) tree nooit geïsoleerd van die voor-Pase Jesus-tradisie (verkondigende Jesus) na vore nie. Met histories-kritiese ondersoeke kan daar tot ' $n$ beperkte mate onderskei word tussen ' $n$ historiese profiel van Jesus en die verskillende profiele wat deur die evangeliste van Jesus daargestel is.

Teologies dien navorsing oor die historiese Jesus die geloofwaardigheid van die kerk. Van Eck (2012:65) sê tereg dat die Reformatoriese tradisie nie bo kritiek verhewe is nie (vgl. Van Aarde 2001:202). Dit is vanselfsprekend dat die kerk se oortuigings gemeet moet word aan die saak wat deur Jesus verkondig is. Dit is inderdaad moontlik dat die kerk die Jesus-saak kan verduister. Dit is ook moontlik dat die kerk binne 'n gegewe konteks kultuur met kanon kan verwar en eersgenoemde laasgenoemde kan vervang wanneer daar na die Jesus-saak gevra word. Hierdie risiko word verhoog wanneer daar nie erns gemaak word met die aanduibare verskil tussen die Jesus-saak en die Jesus-gemeenskappe se tradisies wat in die Bybel voorkom nie. Hierdie teologiese noodsaaklikheid vir navorsing oor die historiese Jesus het 'n inherente etiese dimensie aangesien die kerk as volgelinge van Christus, Jesus se lewe as rigtinggewend beskou. Dit sou onverantwoordelik wees om nie erns te maak met die soeke na Jesus van Nasaret se verkondiging van die koninkryk van God nie. Deur die Jesus-saak (die kontinuïteit tussen leringe van Jesus en die verkondiging van die vroeë kerk) aan te toon, bied navorsing oor die historiese Jesus vir die kerk die rigtinggewende leiding wat telkens weer in veranderende samelewings opnuut interpreteer kan word, byvoorbeeld nie-gewelddadigheid, inklusiwiteit van alle mense in die koninkryk van God en die onbemiddelde teenwoordigheid van God (vgl. Van Aarde 2001:77, 113-114; Van Eck 2007). Dit gee dan ook op hierdie wyse aan die apostolaat van die kerk inhoud.

Van Eck (2012:67) voer aan dat Jesus Christus nie meer alleenbesit van die kerk is nie (vgl. Van Aarde 2001:203). 'n Menigte kontemporêre boeke, artikels en films beeld Jesus uit op 'n wyse wat nie ooreenstem met die Bybelse beeld van Jesus nie. Indien die kerk die Bybelse Jesus daarenteen wil uitbeeld, is ' $n$ historiese ondersoek na die persoon nodig. ${ }^{10}$

\footnotetext{
10. Hierdie argument van Van Eck is uiters gepas na afloop van die finale besprekingspunt wat deur die 70ste Algemene Kerkvergadering (AKV) van die Nederduitsch Hervormde Kerk van Afrika (NHKA) (2013:349) behandel is. In die bespreking van beskrywingspunt 66 aangaande seksualiteit/homoseksualiteit, op 27 September 2013, lig 'n afgevaardigde sy kommer oor die aanvaarding van die beskrywingspunt wat voorstel dat die AKV 'besluit om geen onderskeid te maak in seksuele oriëntasie in besluite wat lidmate of ampsdraers raak nie'. Die afgevaardigde verwys na die gerugte dat daar tans'n film genaamd Corpus Die afgevaardigde verwys na die gerugte dat daar tans " $n$ film genaamd Corpus Christi vervaardig word waarin Jesus en sy dissipels na bewering as homoseksuee uitgebeeld sou word. Volgens die afgevaardigde sou ' $n$ aanvaarding van die ceskrywingspunt 'ook die deur vir daardie moontlikheid oopmaak'. Alhoewel die argument myns insiens nie houdbaar is nie, dui dit tog die realiteit aan dat Jesus nie meer die alleenbesit van die kerk is nie. Die geloofsgemeenskap kan gerusgeste word deur die kerk se ernstige en daadwerklike ondersoeke en uitbeelding van die historiese Jesus, aangesien dit kan verseker dat sekulêr verwronge beelde van Jesus nie die geloof bedreig nie.
} 
Die NHKA bevind sigself tans in 'n onsekere sosiale en politieke klimaat. Die vraag vir die NHKA is, soos dit nog altyd die geval behoort te gewees het, hoe daar te midde van kontemporêre verwikkelinge met die wêreld omgegaan word. God en die geloof in God bly altyd bestaan, maar die wêreld en die betekenisvolle uitdrukking van geloof sal aan verandering uitgelewer wees. Botha (2009:6) is dit eens met Van Aarde (2003:550) dat die kerk en kanon in die ewigveranderende wêreld besig is om invloed en betekenis te verloor. Juis hierdie veranderende historiese onstabiliteit is volgens Botha die sterkste motivering om die verhouding tussen die 'historiese Jesus en die verkondigde Christus' herhaaldelik opnuut aan te dui. Die uitdaging, so meen Botha, is om 'n antwoord op die vraag na hierdie verhouding te vind wat vir die huidige tyd betekenis het. Ten einde so 'n antwoord te bied, sal die Bybelwetenskap egter in staat moet wees om sowel 'n kontinuïteit as 'n diskontinuïteit tussen die voor- en na-Pase Jesus aan te toon. Hierin is navorsing oor die historiese Jesus instrumenteel.

De Villiers (2011:4) meen dat Van Aarde se boek, Fatherless in Galilee, wat die produk van navorsing oor die historiese Jesus is, die Suid-Afrikaanse gelowige en die NHKA in besonder uitgedaag het om histories oor Jesus te besin (vgl. Le Roux 2002:97). Daar sal indringend gevra moet word na die oorsprong van ons geloof en probeer moet word om die waaragtig menslike karakter van Jesus binne die konteks van sy leefwêreld te waardeer. In 'n tyd waar die deursneë lidmaat toegang tot baie meer inligting as in die verlede het, behoort predikante die Kerk se geloof vanaf kansels te kan verantwoord. Myns insiens sal navorsing oor die historiese Jesus 'n sleutelrol in hierdie verband speel mits dit altyd aan die belydenis van die Kerk gemeet word.

\section{Erkenning \\ Mededingende belange}

Die outeur verklaar hiermee dat hy geen finansiële of persoonlike verbintenis het met enige party wat hom nadelig of voordelig kon beïnvloed het in die skryf van hierdie artikel nie.

\section{Literatuurverwysings}

Barthes, R., 1957, Mythologies, transl. A. Lavers, Hill \& Wang, New York, NY.

Borg, M.J., 2011, Speaking Christian: Why Christian words have lost their meaning and power, SPCK, London.

Botha, P.J.J., 2009, 'Historical Jesus research and relevance in South Africa', HTS Teologiese Studies/Theological Studies 65(1), Art. \#154, 11 pages. http://dx.doi. org/10.4102/hts.v65i1.154

Bultmann, R., [1921] 1967, Die Geschichte der Synoptischen Tradition, 7th edn., Van den Hoeck \& Ruprecht, Göttingen.

Bultmann, R., [1926] 1988, Jesus, new edn., Mohr Siebeck, Tübingen.

Bultmann, R., [1933] 1969, 'The significance of the historical Jesus for the theology of Paul', in R. Bultmann (eds.), Faith and understanding, vol. 1, ed. with an introduction by R.W. Funk, transl. L.P. Smith, pp. 220-246, SCM Press, London.

Bultmann, R., [1940-1950] [1976] 1985, The second letter to the Corinthians, transl. R.A. Harrisville, Augsburg, Minneapolis, MN
Bultmann, R., 1952, Die Erforschung der Synoptischen Evangelien, J.C.B. Mohr, Tübingen.

Bultmann, R., [1960] 1965, Das Verhältnis der urchristlichen Christusbotschaft zum historischen Jesus, 4th edn., Carl Winter Universitätsverlag, Heidelberg.

De Villiers, G., 2011, 'Andries van Aarde - A sideways glance: His theological and hermeneutical contribution to the South African scene', HTS Teologiese Studies/ Theological Studies 67(1), Art. \#1033, 10 pages. http://dx.doi.org/10.4102/hts. v67i1.1033

Dorn, L.D., Dahl, R.E., Woodward, H.R. \& Biro, F., 2006, 'Defining the boundaries of early adolescence: A user's guide to assessing pubertal status and pubertal timing in research with adolescents', Applied Developmental Science 10(1), 30-56. http://dx.doi.org/10.1207/s1532480xads1001_3

Groenewald, J. \& Van Aarde, A.G., 2006, 'The role alternate states of consciousness played in the Baptism and Eucharist of the earliest Jesus-followers', HTS Teologiese Studies/Theological Studies 62(1), 41-67. http://dx.doi.org/10.4102/hts.v62i1.356

Jacobs-Malina, D., 1993, Beyond patriarchy: The images of family in Jesus, Paulist Press, New York, NY.

Jeremias, J., 1971, New Testament theology: The proclamation of Jesus, vol. 1, transl. J. Bowden, Charles Schribner's Sons, New York, NY.

Käsemann, E., 1969, Blind alleys in the 'Jesus of history' controversy, transl. W.J. Montague, SCM Press, London. (New Testament Library).

Le Roux, J.H., 2002, 'Andries van Aarde se vaderlose Jesus', HTS Teologiese Studies/ Theological Studies 58(1), 77-99. http://dx.doi.org/10.4102/hts.v58i1.548

Levpušček, M.P., 2006, 'Adolescent individuation in relation to parents and friends: Age and gender differences', European Journal of Developmental Psychology 3(3), 238-264. http://dx.doi.org/10.1080/17405620500463864

Meier, J.P., 1991, A marginal Jew: Rethinking the historical Jesus: The roots of the problem and the person, vol. 1, Doubleday, New York, NY

Nederduitsch Hervormde Kerk van Afrika (NHKA) , 1987, Diensboek, Kital, Pretoria.

Nederduitsch Hervormde Kerk van Afrika (NHKA), 2013, 70ste Algemene Kerkvergadering (AKV), NHKA Kerkargief, Pretoria.

Osborn, R.T., 1990, 'The Christian blasphemy: A non-Jewish Jesus', in J.H. Charlesworth (ed.), Jews and Christians: Exploring the past, present and future, pp. 211-238, Crossroad, New York, NY.

Schille, G., 1994, 'Die Jesusbewegung und die Entstehung der Kirche', Theologische Literatur Zeitschrift 119, 100-112.

Schillebeeckx, E., 1974, Jezus: Het verhaal van een levende, 2nd edn., H. Nielsen, Bloemendaal.

Tatum, W.B., 1994, John the Baptist and Jesus: A report of the Jesus Seminar, Polebridge, Sonoma, CA.

Trilling, W., 1978, 'Impliziete Ekklesiologie: Ein Vorschlag zum Thema 'Jesus und die Kirche', in W. Trilling (ed.), Die Botschaft Jesu: Exegetische Orientierung, pp. 57-72, Herder, Freiburg.

Van Aarde, A.G., 1994, Kultuurhistoriese agtergrond van die Nuwe Testament: Die eerste-eeuse Meditereense sosiale konteks, Kital, Pretoria.

Van Aarde, A.G., 1999, 'Dekonstruksie van Dogma: 'n Eietydse ondersoek na die spore van die leer van die twee nature van Jesus', HTS Teologiese Studies/Theological Studies 55(2/3), 437-470. http://dx.doi.org/10.4102/hts.v55i2/3.1594

Van Aarde, A.G., 2001, Fatherless in Galilee: Jesus as child of God, Trinity Press International, Harrisburg.

Van Aarde, A.G., 2003, 'Does historical Jesus research have a future?', Verbum et Ecclesia 24(2), 533-556. http://dx.doi.org/10.4102/ve.v24i2.325

Van Aarde, A.G., 2004, 'Social identity, status envy, and Jesus as fatherless child', in J.H. Ellens \& W.G. Rollins (eds.), Psychology and the Bible: A new way to read the Scriptures, From Christ to Jesus, pp. 223-246, Praeger Press, Westport. (Praeger Perspectives: Psychology, Religion, and Spirituality).

Van Aarde, A.G., 2012, 'Fatherless in Galilee: 'n Outobiografiese Refleksie', openbare lesing, Hervormde Teologiese Kollege, Universiteit van Pretoria, 31 Oktober.

Van Aarde, A., 2013a, 'Fatherless in Galilee: 'n Outobiografiese refleksie', Verbum et Ecclesia 34(2), Art. \#856, 8 pages. http://dx.doi.org/10.4102/ve.v34i2.856

Van Aarde, A.G., 2013b, 'The tomb cult of the early Jesus-followers in Jerusalem', in J.H. Ellens (ed.), Heaven, hell, and the afterlife: Eternity in Judaism, Christianity, and Islam, End time and afterlife in Christianity, vol. 2, pp. 31-48, Praeger, Santa Barbara, CA.

Van Aarde, A.G. \& Joubert, S.J., 2009, 'Social-scientific criticism', in A.B. du Toit (ed.), Focusing on the message: New Testament hermeneutics, exegesis and methods, pp. 419-456, Protea, Pretoria.

Van Eck, E., 2007, 'The tenants in the vinyard (GThomas 65/Mark 12:1-12): A realistic and social-scientific reading', HTS Teologiese Studies/Theological Studies 63(3), 909-936. http://dx.doi.org/10.4102/hts.v63i3.233

Van Eck, E., 2009, 'Interpreting the parables of the Galilean Jesus: A social-scientific approach', HTS Teologiese Studies/Theological Studies 65(1), Art. \#308, 12 pages. http://dx.doi.org/10.4102/hts.v65i1.308

Van Eck, E., 2012, 'Christologie: Die ondersoek na die historiese Jesus', ongepubliseerde klasnotas, NTW 810-2, Departement Nuwe Testament, Fakulteit Teologie, Universiteit van Pretoria, Pretoria. 